\title{
French Policy and the Hajj in Late-Nineteenth-Century Algeria: Governor Cambon's Reform Attempts and Jules Gervais-Courtellemont's Pilgrimage to Mecca
}

\author{
Aldo D’Agostini
}

The history of colonial policies shows the spectacle of myths and prejudices transforming into concrete administration practices and ideological discourses towards Islam and Muslim societies. At the same time, however, colonial history included a number of examples of attempts that were made by openminded individuals or small groups in order to discard such prejudiced practices and discourses by means of reforming colonial policies and mentality. These attempts, which usually resulted in failure, are generally dismissed by historians as "exceptions which confirmed the rule." In reality, by focusing on such examples we can better understand how the prejudices and myths had worked in the colonial praxis.

The French governance of the Hajj, in the nineteenth century, represents a good field of enquiry for this particular historical approach. Though inspired in part by humanitarian worries about the spread of diseases, this governance was indeed influenced by many myths and prejudices which can be attributed to a strong sense of Islamophobia in that era. In this chapter we will draw attention to two emblematic personalities who, from different positions and with different aims, tried to change the French attitudes towards the Hajj. The first is Jules Cambon (1845-1935), governor-general of Algeria (in the period between 1891-1896), who made the most ambitious attempt to reform the French governance of the Hajj by introducing a more tolerant policy towards the native Muslims. The second is Jules Gervais-Courtellemont (1863-1931), a French photographer and traveller, who grew up in Algeria, converted to Islam, and made a remarkable pilgrimage to Mecca in 1894. As they were simultaneously looking for a French way to the Hajj, their attitudes were quite revolutionary and provoked strong reactions in their time. 


\section{French Policy and the Hajj: Preliminary Considerations}

Throughout the nineteenth century ancient fears and images related to the Crusades and Reconquista reappeared in new forms within the colonial discourse. ${ }^{1}$ At that time, to use Maxime Rodinson's words, the Islamic world started to be perceived again as a "hostile political ideological structure," and discourses arose about "planetary Islamic conspiracy against Europe and Christianity."

The Hajj was frequently evoked in these kinds of discourses. In 1851, for example, Guglielmo Massaia (1809-1889), an Italian missionary and Capuchin friar, held a conference in Paris during which he considered the Holy City of Mecca at the centre of a world-wide conspiracy led by a "reformatory and fanatical party" whose aim was to finally destroy the world. All the pilgrims, returning from the Hajj, indeed became "missionaries of the Koran" by preaching revolution in India and Africa and prepared the "great empire of the future."3 Massaia's speech was reproduced in a brochure that gained popularity in France. ${ }^{4}$ His ideas were also evoked in the French Senate during a debate on the Lebanese crisis.

European myths and prejudices concerning the Hajj, which Massaia reflected in his apocalyptic speech, were particularly developed in the colonial contexts. European administrators looked on with anxiety at the departure of Muslims for Mecca, a city devoid of diplomatic offices and where any methods of surveillance were powerless. The possibility that pilgrims were probably exposed to political propaganda and after their return they would become more fanatical was taken into great consideration. In French Algeria this situation led to the adoption of a policy of repression of the Hajj that sometimes reached a complete ban on it. In other cases, the Hajj was also obstructed by others practices, such as demanding a special passport to Mecca, which was issued under hard economic and political conditions, imposing complicated

1 See Norman Daniel, Islam, Europe and Empire (Edinburgh: Edinburgh University Press, 1966).

2 See Maxime Rodinson, La fascination de l'islam: Les étapes du regard occidental sur le monde musulman: Les études arabes et islamiques en Europe (Paris: Maspero, 1980), 24 and 90-91.

3 Guglielmo Massaia, Lettere e scritti minori (Roma: Istituto Storico dei Cappuccini, 1978), 289321.

4 Many of its references are available, for example, in a book on Arabia, published by a diplomat named Adolphe D' Avril in 1868. See Adolphe D' Avril, L'Arabie contemporaine avec la description du pèlerinage de la Mecque et une nouvelle carte géographique de Kiepert (Paris: Maillet-Challamel Ainé, 1868), 219-222. 
bureaucratic procedures for pilgrims, or strict sanitation requirements for ships transporting pilgrims. ${ }^{5}$

Meanwhile, French administrators generally agreed that an excessive restriction of religious practices would increase the risk of uprisings. Therefore, some of them occasionally highlighted the political advantages of the Hajj by promoting it in the colonial areas. General Bugeaud, for example, thought that a promotion of the Hajj would be a good gesture of "solicitude" of France to Algerians. Moreover, its promotion, according to him, was also a good advantage to send "insubordinate" Muslim subjects away from the colony. In this regard, he stated:

Je pense donc (...) qu'il serait politique de favoriser la consommation de cet acte religieux en donnant à un certain nombre d'indigènes des facilités pour se rendre à Alexandrie. Peut-être même qu' en agissant dans ce sens nous parviendrions à éloigner du pays pendant un certain temps, et même pour toujours, des individus qui auraient été une cause $\mathrm{d}^{\prime}$ inquiétude pour notre domination. ${ }^{6}$

In 1842, stimulated by such considerations, French authorities organised one or two official pilgrim ships. These were the principal ingredients of the French policy towards the Hajj in the nineteenth century, which were also influenced by other factors in French colonial history. In order to situate the policy of Jules Cambon in this history, it is relevant to describe the period which preceded his arrival in Algeria.

\section{Repressive Policy of Governor Tirman 1881-1891}

Between the mid-1870s and mid-188os, the idea of the Islamic world as a hostile politico-ideological structure was present in European public debate. This period was characterised by several international crises related to the so-called

5 See Philippe Boyer, "L' administration française et la réglementation du pèlerinage à la Mecque (1830-1894)," Revue d'Histoire Maghrébine 9 (1977): 275-293; Laurent Escande, "Le pèlerinage à la Mecque des Algériens pendant la domination française (1830-1962)" (DEA diss., Université de Provence, 1992); Luc Chantre, "Se rendre à La Mecque sous la Troisième République: Contrôle et organisation des déplacements des pèlerins du Maghreb et du Levant entre 1880 et 1939," Cahiers de la Méditerranée 78 (2009), accessed March 31, 2014, url: https://cdlm.revues .org/4691.

6 Quoted in Boyer, "Administration française," 279. 
"Eastern Question." The most important of these were: the Bulgarian crisis (1876), the Russo-Ottoman War (1877-1878), the British occupation of Afghanistan (1879), the French occupation of Tunisia (1881), the Egyptian crisis (18811882), and the uprising of the Mahdi in Sudan (1881-1885). These crises lead to drastic change in the balance of power between European States and the Muslim world. The possibility of a collapse of the Ottoman Empire suggested the idea of a geopolitical void that was imbued by feelings of anxiety and fuelled by an increase of imperialistic competition. In this context the increasing appearance of such concepts as "Islamic danger" or the "Yellow peril" spread fear into different colonial geographical spaces. The concept of Islamic danger, in that period, was represented by different actors and phenomenon, such as the Mahdi of Sudan, "pan-Islamic politics" of sultan Abdülhamid II, or the Sanūsī order of Cyrenaica. ${ }^{7}$ Created mostly by diplomats, such épouvantails soon spread into propaganda media, generating an atmosphere of increasing Islamophobia in France.

This situation obviously had a great impact on French policy towards the Hajj. Under Governor Tirman (1881-1891), the repressive measures reached a boiling point on many levels. In 1882, for example, Tirman recommended strict police surveillance of any foreigner, Muslim or European, passing through Algeria. ${ }^{8}$ Also, any Algerian who wanted to travel abroad had to follow a specific itinerary that should be previously agreed on by French authorities. ${ }^{9}$ NonAlgerians were prohibited from being musicians, singers, amulet-sellers, acrobats, and snake-charmers. ${ }^{10}$ Concerning the Hajj, he finally decided that, when not completely banned, only a few passports were to be issued to the degree that all applications of travel permits were directly checked by him. ${ }^{11}$ For him

See Jean-Louis Triaud, La légende noire de la Sanûsiyya: Une confrérie musulmane saharienne sous le regard français (1840-1930) (Paris: Éditions de la Maison des sciences de l'homme, 1995).

Circular n. 7, 15 June 1882, Gouverneur Général (GG) Tirman, "Au sujet de la surveillance à exercer à l'égard des étrangers Européens ou Musulmans, voyageant en Algérie," (confidentiel), Archives National d'Outre-Mer (ANOM), $1 \mathrm{HH}_{5} 8$ ("Circulaires—du 1/1/1877 au 11/4/1911"), ff. 177-178.

9 Circular n. 10, 30 June 1882, GG Tirman, "Au sujet des étrangers voyageant en Algérie à surveiller étroitement," АNOM, $1 \mathrm{H}_{5} 8$, f. 180.

Algerians, instead, could practice these professions only in the district (cercle) in which they lived. Circular n. 13, 22 July 1882, G G Tirman, "Mesures à prendre contre les musulmans d'Algérie ou étrangers exerçant les professions de musicien, bateleur, chanteur, charmeur de serpent, vendeur d' amulettes ...", ANOM, $1 \mathrm{HH}_{5} 8$, ff. 182-183.

11 Circular n. 31, 24 April 1884, GG Tirman, "Règles et conditions du pèlerinage en 1884," ANOM, 1H H58, ff. 206-207: “Dans ces conditions je me réserve d' accorder moi-même les 
the Hajj was nothing but a "school of fanaticism" and a practice which was "essentially injurious to religious tolerance." Therefore France had to push Algerians to spontaneously abandon the Hajj so that a sense of "religious tolerance" would reign in the colony:

Car le pèlerinage ne saurait être qu' une école de fanatisme religieux, et le fanatisme religieux est sans contredit le plus grand obstacle que puisse rencontrer l' œuvre de consolidation de notre conquête. (...) Pour résumer en un mot, l' expression de mon sentiment, je dirais que le pèlerinage de la Mecque doit être, à l' avenir, simplement toléré; et je suis persuadé qu'en suivant la règle que je viens de tracer nous amènerons sans froissement les indigènes à renoncer eux-mêmes, chaque jour davantage, pour leur plus grand bien, à une coutume essentiellement nuisible à la tolérance religieuse qu'il est de notre devoir d' essayer de faire pénétrer dans l' esprit de la population arabe. ${ }^{12}$

International crises, such as the Egyptian national uprising or the Mahdi revolution in the Sudan, were frequently used as arguments to justify a complete ban on the Hajj. Governor Tirman, for example, argued that pilgrims, along their itinerary, "were probably exposed to dangerous influences by witnessing some acts of war which they would report to their tribes upon returning to Algeria." ${ }^{13}$ In other words, he confirmed:

... les événements dont notre Extrême Orient est le théâtre [he means Egypt] sont graves et il n' est pas douteux que sur une notable partie du trajet à accomplir, nos pèlerins ne trouveraient plus la sécurité nécessaire, qu' ils seraient exposés à de dangereuses suggestions et seraient peut-être les témoins d'actes de guerre qui ne manqueraient d'être racontés dans les tribus avec toutes les amplifications habituelles. ${ }^{14}$

autorisations nécessaires en vue des propositions que vous me soumettrez en accompagnant chacune d' elles de votre avis motivé et d' une notice individuelle sur les antécédents, la conduite et la fortune des intéressés."

12 Circular n. 21, 4June 1883, G G Tirman, "Pèlerinage de la Mecque," ANOM, 1H H58, ff. 193-195.

13 Circular n. 15, 17 August 1882, G G Tirman, "Pèlerinage de la Mecque," ANOM, 1H H58, ff. 184187.

14 Circular n. 15, 17 August 1882, G G Tirman, "Pèlerinage de la Mecque," ANOM, 1H H58, ff. 184187. 
This was also fuelled by a number of rumours coming from diplomatic circles. Henri Fournier (1878-1880) and Joseph Tissot (1880-1882), French ambassadors in Istanbul, kept alarming the French government by sending letters and telegrams warning about intrigues associated with the idea of a pan-Islamic conspiracy. ${ }^{15}$ At the same time, the French consul to Tripoli, Charles Féraud, constantly warned against the "dangerous" Sanūsi order of Cyrenaica. ${ }^{16}$ According to him, this "sect" was using propaganda among Algerian pilgrims passing through Cyrenaica and Tripolitania. ${ }^{17}$ Such rumours, as well as the crisis of the Eastern Question, caused geopolitical panic in public opinion and consequently had vigorous impact on decisions made by French authorities. In 1882, for example, Tirman banned the Hajj for the fear that public opinion would be rightly alarmed if, in the actual circumstances, the trip were to be carried out as usual:

Enfin, l'opinion publique européenne en Algérie, qui s' est toujours prononcée contre le pèlerinage dont les inconvénients au point de vue politique et sanitaire ne sont pas à démontrer, l'opinion publique dis-je serait justement alarmée, si dans les circonstances actuelles, le voyage s' accomplissait comme à l' ordinaire. À l'interdiction absolue de l' année dernière, nous sommes donc obligés de faire succéder une mesure semblable. Toutefois, comme nous avons un intérêt de premier ordre à ne pas

15 For an analysis of these documents see Joseph Hajjar, L'Europe et les destinées du ProcheOrient III: Bismarck et ses menées orientales 1871-1882 (Damascus: Dar Tlass, 1990), 12531339 and Aldo D'Agostini, "De l'usage diplomatique du discours sur le panislamisme: La correspondance de l'ambassadeur français à Istanbul Charles-Joseph Tissot, lors de la crise tunisienne de 1881," Archiv Orientální / Oriental Archive:Journal of African and Asian Studies 81/2 (2013): 149-172. In addition to Fournier and Tissot, we must also mention Ambassador de Burgoing who, in a letter dated July 15, 1876, first talked about a religious propaganda made by "travelling dervishes," "pilgrims from Mecca," and other "dangerous preachers." See “Evénements de Turquie 1876-1878: conséquences," ANOM, 1H31.

16 See Triaud, La légende noire.

17 See for example Consul Féraud to Ministre des Affaires Etrangères (MAE), Tripoli, May 10, 1880, "Situation politique de la Tripolitaine," AmAE, Correspondance Consulaire (CC), Tripoli de Barbarie, vol. 18, ff. 105-110. The correspondence of Féraud was frequently evoked in Tirman's circulars. One of these circulars also contained a quotation from a consul's letter. In this letter Féraud, among others, informed that he had decided to put a red mark on the passports of all Algerians traversing Tripoli in order to help their colleagues in Alger to better control them. See circular n. 24, 21 July 1880, G G Tirman, "Au sujet des pèlerins indigènes passant par Tripoli et soupçonnés d' aller visiter le Cheik Snoussi," ANOM, 1H H58, ff. 117-118. 
laisser s'établir dans l'esprit de nos sujets musulmans la conviction que nous voulons apporter des obstacles définitifs au pèlerinage et violenter leur foi, j' estime qu' il faut éviter de donner à cette interdiction, un caractère absolu et si des personnalités indigènes dont le passé nous offrirait des garanties spéciales, venaient à formuler des demandes de passeport, et s'il vous semblait qu'il y eut un intérêt politique à ne pas les froisser par un refus, vous auriez à m' en référer. ${ }^{18}$

\section{French Consuls in Jeddah (1882-1891)}

While the Hajj was perceived as a danger in Algeria, the French Vice-Consulate of Jeddah did not underestimate its political and economic advantages for the French government. In 1882, the French vice-consul Suret drew the attention of the French Foreign Ministry to the political relevance of the Hajj by underscoring the fact that a "free pilgrim" was always better than a "hindered pilgrim," who was certainly more sensitive to enemy propaganda. He stated that "Le pèlerin libre ne songe qu'à son acte de dévotion et rarement il revient chez lui aussi fanatique qu' il l' était au départ, (...). Le pèlerin empêché devient doublement dangereux: par son propre mécontentement et pour l' habilité de ceux qui savent l' exploiter."19 Suret also denounced exaggerations concerning the sanitary danger of the Hajj and tried to obtain a Muslim doctor from the ministry for medical support. Such a medical post at the Consulate could, according to him, "save Europe from many diseases, and in particular from its recurrent panic." 20

In 1888 , the recently appointed general-consul Watbled wrote a rich report on the political advantages of a French governance of the Hajj. ${ }^{21}$ This French

18 Circular n. 15, 17 August 1882, Gg Tirman, "Pèlerinage de la Mecque," ANOM, 1H H58, ff. 184187.

19 Vice Consul Suret to MAE, 31 May 1882, ANOM, 16H84 ("Pèlerinage à La Mecque"). It is important to underline that Consul Suret wrote this letter to the government in order to express his disappointment concerning Tirman's decision to ban the Hajj in that year. At the beginning of the letter he said: “Hier j' ai appris, peut-être m'a-t-on induit en erreur, que M. le Gouverneur général de l' Algérie avait interdit le pèlerinage pour cette année, et j' en ai été fort ému." Ibid.

20 Édouard-Florent Suret, Lettre sur le cholera du Hedjaz (Paris: Masson, 1883), 18. “... préserver l'Europe de beaucoup de maux, et en particulier de ces paniques périodiques."

21 While Suret's letter was an extemporary initiative, Watbled's report is the first of a long series of annual reports on the Hajj that rapidly became one of the most important references for French policy in the Hijāz. The reports from 1888 to 1923 are available 
Hajj policy, according to him, had to focus mostly on measures that should guarantee the safety of Algerian pilgrims, who would fall victim to many outrages. If these pilgrims had felt some protection from France at the centre of the Muslim world, they would certainly have returned to Algeria with a greater regard for their French rulers. In his view:

Cette protection du Consulat français de Djeddah, constamment en éveil et avec succès n' a pu que frapper l' esprit des Maghrébins, et selon moi, c' est le meilleur moyen de nous les rattacher. Le Coran dit 'Soyez forts sur la terre parce que la Force est la manifestation de la divinité.' Les sujets français qu' ont traversé cette année l'Hedjaz emportaient certainement une haute idée de l'influence exercée par la France en pays musulmans: résultat auquel ont tendu tous nos efforts. ${ }^{22}$

The following year, Watbled emphasized the necessity of creating a French monopoly on pilgrim "trade" in order to protect "national trade." He also recommended the significance of supporting and protecting the activities of the Compagnie Fabre steamship line in Marseille, which had already entered the pilgrim trade business, but faced great difficulties because of British and Italian (Compagnia Rubattino) competition. ${ }^{23}$

As we see, by the end of the 1880 s, French diplomacy started to look at the Hajj from a more imperialist perspective by considering it as an opportunity to spread French economic and political influence in the Red Sea and Arabian Peninsula. ${ }^{24}$ Watbled's successor, Lucien Labosse, continued this promotion of a French governance of the Hajj. In a report in 1890, he confirmed that Algerian pilgrims, far away from their country, started to become suspicious of the grandeur of France: "En quittant le sol qui les a vus naître, nos sujets perdent beaucoup de leurs illusions et de leurs préjugés. Le cercle de leurs conceptions s' élargit. Ils commencent alors à soupçonner la grandeur de la France."25

Some of the measures he listed in order to regulate the Hajj included the creation of charitable societies in Jeddah and the dispatching of dragomans who

in ANOM, $16 \mathrm{H} 83$ ("Rapports des agents diplomatiques et renseignements divers sur la situation au Hedjaz 1888-1923").

Consul Watbled to MAE, 9 September 1888, ANOM, $16 \mathrm{H} 83$.

23 Watbled to MAE, 1889, АNOM, $16 \mathrm{H} 83$.

24 See, for example, William Roff, "Sanitation and Security: The Imperial Powers and the Nineteenth Century Hajj," in Arabian Studies VI, ed. R. Serjeant, and R. Bidwell (London: Scorpion Communication-University of Cambridge, 1982), 143-160.

25 Consul Labosse to MAE, 1890, AMAE, 16H83, f. 22. 
would accompany pilgrims during their journey. This detailed report of Consul Labosse was submitted to Jules Cambon, who was recently nominated as governor-general of Algeria in April 1891. Having studied the report, he decided to re-open the way to Mecca for Algerian pilgrims as means of exploiting any political potential advantages of the Hajj. His initiative also included a great plan of reform, which Jules Cambon intended to fulfil in French Algeria.

\section{Colonial Strategy of La Famille: Jules Cambon's Political Background}

Born in 1845, Jules Cambon belonged to a generation of French administrators who participated in the creation of the Third Republic and later became very active in this new regime. Together with his brother Paul, Jules Cambon joined a circle of young disciples of Adolph Thiers who shaped the ideas around the Journal des débats politiques et litteraires. At the end of the 1870s, the Cambon brothers and other members of this circle created a confidential society called La Famille whose aim was to exchange information and to facilitate the career of its members. ${ }^{26}$ Among its members were the three Charmes brothers (Francis, Xavier and Gabriel) who, in collaboration with Paul and Jules Cambon, became the leaders of the group. ${ }^{27}$ Francis Charmes, in particular, played a very strategic role inside the French Foreign Ministry, while Gabriel Charmes became a well-known journalist and a propagandist for the group.

La Famille rapidly succeeded in constituting a lobby inside the French administration which enabled them to play an important role, particularly in foreign affairs and colonial policies. In their vision, France had to become a more competitive empire by integrating its colonial policies into a more global strategy and foreign interests. They preferred the form of protectorate above settler colonies and highly recommended a policy of "association" with local powers. In this policy the Islamic character of the French Empire should be stressed. In his articles, Gabriel Charmes affirmed that France was a "great

26 See Laurent Villate, La République des diplomates: Paul et Jules Cambon 1843-1935 (Paris: Science Infuse, 2002); Christophe Charle, Les Élites de la République 1880-19oo (Paris: Fayard, 1987), 437.

27 In 1880, Paul Cambon, in a letter to his wife, described the five men as five fingers of the hand. Villate, La République des diplomates, 24. According to Villate, others members of La Famille were Georges Patinot, Adrien de Montebello, Georges Pallain, Jules Develle and Emile Roux (ibid.). 
Muslim power and the only European Arab power, after Turkey."28 If France had succeeded in civilising the Muslim population of North Africa, he argued, these peoples would have become the propagators of French influence in the Mediterranean and a powerful instrument to fight the "pan-Islamic politics" of the Ottoman Empire. In short, Islam had to become a weapon in the hands of French imperialism. ${ }^{29}$

In order to achieve this goal, La Famille had to drastically change the traditional French colonial policy. In 1882-1886, Paul Cambon, during his office as Résident Général of Tunis, tried to apply the colonial program of La Famille by involving native Muslims in the governance of the new French protectorate. ${ }^{30}$ His efforts, however, were obstructed by the colonial civil society and by the army. A few years later, in 1891, his brother Jules Cambon's appointment as a successor to Tirman in Algeria gave La Famille a second chance to influence French colonial policies in Algeria.

\section{A Policy pleine d'égards for Algerian Muslims (1891-1896)}

By the end of the era of Napoleon III, the situation in Alger had rapidly changed. The influence of Europeans settlers had increased and the traditional military system of administration, based on a web of bureaux arabes, had been progressively dismantled. By 1881, a new system of rattachement was created to rule the three departments of Algeria (Alger, Oran, and Constantine) as any other department of France. Practically, the local services were linked (rattachés) to their correspondent ministries in Paris. European settlers started to elect their deputies at the Asssemblé Nationale and the governor lost much of his power.

28 Gabriel Charmes, La Tunisie et la Tripolitaine (Paris: Calmann Lévy, 1883), 14: “La France est une grande puissance musulmane et la seule puissance arabe de l'Europe, après la Turquie. Depuis le jour où nous sommes descendus, où nous nous sommes fixés sur la côte d' Algérie, nous avons cessé d'être uniquement une nation chrétienne; nous sommes devenus en outre une nation islamique, et il ne nous a plus été permis de rester indifférents aux révolutions de l' Islam."

29 See Charmes, Tunisie et Tripolitaine, 441-442.

30 Gabriel Charmes, who soon reached his friend in Tunis, published a series of letters in the Journal des débats in which he made a detailed description of the plan of reforms proposed by the Résident Général. These letters were later collected in a book entitled La Tunisie et la Tripolitaine (Paris: Calmann Lévy, 1883). The collection could be seen as a manifest of La Famille. A few years later, in 1885, Gabriel Charmes published another book entitled Politique extérieure et coloniale (Paris: Calmann Lévy) in which he placed the subject in a much more global and geopolitical perspective. 
This new system was characterised by great corruption and outrage against Muslims. ${ }^{31}$ Tirman's above-mentioned repressive measures should be placed in this particular phase. The increase of corruption and outrage soon caused anxiety in political circles in France. In 1891, a senatorial commission was sent to Algeria to inquire about the situation. As a result of this commission's inquiry, Jules Cambon was chosen as the new governor replacing Tirman. ${ }^{32}$ His mission was to put Algeria under the control of the metropolis again and to change the course of colonial policy. In that sense, he was expected to show to Algerians the "solicitude" of France, ${ }^{33}$ to "safeguard the dignity of the defeated," and to achieve a "moral conquest" of Algeria. ${ }^{34}$

Cambon soon prepared a detailed plan of reform which he explained before the French Parliament and at the Algerian Council. The principal points of his program included: 1) the fight against usury which was going to destroy the native property; 2) combating corruption by excluding any administrators who were responsible for outrage against the natives; 3 ) the creation of a new forestry law that could better defend native economic interests; 4) reforming the Supreme Council of Algeria and municipalities by including local delegates; 5) the building of schools for natives; 6) the creation of an official Muslim clergy financed by the state; and 7) the organisation and regulation of the pilgrimage to Mecca. As we see, Cambon's program mostly intended to give local Muslims more space in ruling their country, which is known among historians as politique des égards. ${ }^{35}$ This policy was accompanied by symbolic initiatives intended to demonstrate the solicitude of France towards Muslims. For example, Cambon granted the son of the chief of the Taybiyya, a local Sufi order, the title of Légion d'honneur. He also delivered a solemn speech during the funeral ceremony of the chief of the Tijāniyya Sufi order. ${ }^{36}$

31 See Didier Guignard, L'abus de pouvoir dans l'Algérie coloniale (1880-1914): Visibilité et singularité (Paris: Presses Universitaires de Paris Ouest, 2010).

It is important to mention that Jules Cambon had already worked in Algeria in the period 1874-1879 as team member of Governor Chanzy (1874-1876) and later as Prefect of Constantine (1879). During this period, he worked on a project of marital status for native Muslims in Algeria. See Villate, La République des diplomates.

"Vous avez une double tache à remplir. Vous avez d' abord à prouver aux indigènes la sollicitude de la France et à leur rappeler que nous les aimons. Vous avez ensuite à assurer vis-àvis des parlementaires l' indépendance de notre administration." Sadi Carnot to Jules Cambon, quoted in Geneviève Tabouis, Jules Cambon par l'un des siens (Paris: Payot, 1938), 44.

34 Charles-Robert Ageron, Les Algériens musulmans et la France (1871-1919) (Paris: Presse Universitaire de France), 478.

35 Ageron, Les Algériens musulmans.

36 Ibid., 513. Cambon's policy towards the Sufi orders resulted in the edition of Octave 
Cambon's clever and well-articulated policy was not completely welcomed in French colonial offices. His plans were obstructed by the colonial civil society and old administrative traditions. In 1893, Cambon confidentially told one of his collaborators: "the dullness which you can find in some departments does not help me at all."37 Etienne and Thompson, deputies of Algeria in the Parliament, made a strong lobbying effort against his reform plans which resulted in his removal from his post. Cambon, however, managed to dismantle the rattachement system that was finally abolished in 1896.38

\section{Cambon's Hajj Policy (1891-1894)}

Cambon's reopening of the way to Mecca for Algerian Muslims gave a strong and immediate signal of a change in French colonial policy. By this he demonstrated the "solicitude" of France and presented himself as the defender of Muslim rights. Moreover, he could materialise the idea of France as a Muslim power by making the Hajj a symbol of French good-will towards Islam. In his official writings, he often refers to local Algerians as "our Muslims." Moreover, he tried to exploit the Hajj to establish relationships with religious leaders of the Hijāz. Finally, just as the rest of his reform program, Cambon's policy was not fulfilled because of a misunderstanding between him and the French Consulate of Jeddah, mistrust and overruling of French administration, and a counterproductive atmosphere in French public opinion.

We have seen that the French Consulate in Jeddah was amenable to French control of the Hajj, and the consuls (Suret, Watbled, and Labosse) had already put forward many suggestions to the foreign office in Paris. In the beginning Cambon collaborated with Consul Labosse, but they soon developed conflicting attitudes towards the Hajj. In 1891, Cambon organized the first Hajj trip during his office. Two steamships (Gallia and Pictavia) sailed with 1,527 pilgrims onboard to Jeddah. They were provided with fumigants and other varieties of medical equipment and a French doctor, M. Delarue. ${ }^{39}$ In his annual report,

Depont and Xavier Coppolani, Les confréries religieuses musulmanes (Alger: Jourdan, 1897). The book was intended to give French administrators an instrument for day-by-day political activities. See George Trumbull IV, An Empire of Facts: Colonial Power, Cultural Knowledge, and Islam in Algeria (Cambridge: Cambridge University Press, 2009).

Villate, La République des diplomates, 101: "L'étroitesse d'esprit dont on fait preuve dans certains bureaux ne m' aide pas dans ma tâche."

38 See the introduction of Jules Cambon, Le Gouverneur Général de l'Algérie (1891-1897) (Paris: Champion, 1918). This volume is a collection of Cambon's speeches and official acts. 
Labosse expressed his satisfaction with the journey by stating that "Algerians could see the difference between the Republic's good care of its 'children' and the attitudes of the other [colonial] governments. ${ }^{\prime 40}$ However, he remarked that if France really wanted to take advantage of the Hajj, it should better protect Algerians from bad treatment by local authorities. In order to control the Hajj, he proposed that pilgrims should be divided into groups of 29 persons led by a sheikh and that all ships be provided with Muslim doctors; some Algerians had to be sent to Mecca before the Hajj season in order to replace the pilgrims' local guides (muțawifin). An Algerian living in Mecca, who was in contact with Labosse, was ready to become a French agent during the Hajj. Indeed, Labosse wanted to use French control of the Hajj in order to exploit its economy as well as to benefit his work of intelligence..$^{41}$ In the next year, Cambon implemented some of Labosse's recommendations, but the consul reported that it was not satisfied yet. He proposed to change the traditional itinerary of the Hajj, which included a visit to Medina after the fulfilment of the rites in Mecca. According to Labosse's new suggestion, Algerian pilgrims had to travel from Medina to Mecca by ship via Yambo and Jeddah in order to reinforce complete control of the Hajj. After Labosse's replacement in December 1892, in a letter to the Ministry of Interiors Cambon expressed his rejection of most of the consul's proposals and recommended full freedom of Algerian pilgrims:

D' une manière générale, j' estime, Monsieur le ministre, que l' administration ne doit intervenir dans les questions de ce genre qu' avec une grande réserve. Les indigènes sont toujours portés à croire que nous cherchons à entraver le pèlerinage; les mesures sanitaires ou autre que nous prescrivons, dans leur intérêt, sont accueillies par eux avec méfiance et presque toujours mal interprétées. Le mieux serait, à mon sens, de leur laisser la plus grande liberté, aussi bien pour discuter et payer le prix de passage et les différents droits auxquels ils sont assujettis, que pour le choix de leur itinéraire, nous bornant aux dispositions adoptées les années précédentes. ${ }^{42}$

rue, Rapport médical de M. Delarue commissionné par M. le Gouverneur général de l'Algérie à bord du Pictavia pour le pèlerinage de la Mecque en 1891 (Alger: Giralt, 1892).

Labosse to MAE, 19 September 1891, ANOM, F.80.1747 (“Pèlerinages à la Mecque"), f. 2:

"Les algériens ont pu voir la différence qui existe entre les attentions bienveillantes de la République pour ses enfants et les autres Gouvernements."

42 Governor Cambon to Ministry of Interiors, 26 December 1892, ANOM, F.80.1747. 
But Cambon's attitude toward Labosse provoked the service consulaire who, from that moment, started to oppose him. The succeeding consul M. Guiot supported Labosse's proposed combinaison, including the change of itinerary. His successor, M. Bobot-Descoutreux, did the same. In sum, Cambon's promotion of the Hajj was above all motivated by his aim of making France popular among Algerian Muslims, whereas the French Consulate in Jeddah was keen on exploiting the Hajj as means of affirming French political authority in the Hijāz and the Red Sea.

In addition to Cambon's difficulties with the Consulate in Jeddah, there was a mistrustful attitude in the French administration. In particular, the Ministry of Interiors, in charge of authorising Hajj travel permits, insisted on complicating Cambon's task. In 1893, for example, the minister delayed issuing Hajj permits by taking a long time to implement Guiot's proposals that caused great confusion in the Hajj organisation of that year. When the minister finally decided to change the itinerary, it became clear that pilgrims accordingly would not be able to reach Mecca before the start of rituals. So, at the last minute, the old itinerary was followed; and Guiot was required to travel to Suez to inform the captains of pilgrim steamships about the new travel route. ${ }^{43}$ Due to the lack of collaboration, Cambon became isolated and frustrated. In 1894, because of another delay of issuing permits, Cambon was forced to cancel the departure of pilgrims.

It is important to take into account the role of French public opinion regarding the asserted political and sanitary dangers of the Hajj in the failure of Cambon's Hajj policy. For instance, in his La défense de l'Europe contre le Cholera, ${ }^{44}$ Dr. Adrien Proust described the Hajj as an enormous sanitary threat to Europe by recommending the adoption of Labosse's restrictive measures on it. In 1893, cases of cholera were found in the South of France at the same time a cholera epidemic hit Mecca. Although the cholera in Mecca had no connection with the cases in France, it confirmed Proust's alarming tone in the public debate. ${ }^{45}$ Besides, press articles were focused on the political "dangers" of the Hajj, which increased the anxiety of French public readers as well. Similar to the abovementioned governor Tirman, many French administrators adopted an overcautious attitude towards the Hajj in order to prevent any eventual disappointment of French public opinion.

\footnotetext{
43 See ANOM, F.80.1747.

44 Adrien Proust, La défense de l'Europe contre le Cholera (Paris: Masson, 1892).

45 In order to reassure French readers, Le Figaro affirmed that Proust had taken "strong measures" against the Hajj. Le Figaro, June 17, 1893.
} 
We have seen that French administrators faced a dilemma between taking the risk of either promoting the Hajj or restricting it in order to protect themselves from its asserted "dangers." In this context, we can read Jules GervaisCourtellemont's following Hajj experience.

\section{Jules Gervais-Courtellemont and his Pilgrimage-Voyage-Mission to Mecca}

Jules Gervais-Courtellemont was born on July 1, 1863 in Avon, Seine-et-Marne, nearby Paris. In 1867, his father, Louis Victor Gervais, died and in the following year, his mother remarried an officer named Jules Georges Courtellemont. ${ }^{46}$ In 1874 he moved to Algeria, where his family bought a farm in the Relizane valley. ${ }^{47}$ When he was 14 years old, he was left alone in the farm when his parents departed to France for health reasons. In this difficult situation, GervaisCourtellemont lived among Algerian peasants of the region who helped him manage his family enterprise. His experience as a young boy undoubtedly influenced his future attitude towards Algerian people and their religion and traditions.

The young Courtellemont was passionately fond of photography and travel. In 1883 , he travelled to Spain; in 1885 , he visited Morocco. In 1891-1892, as a photographer, he joined an archaeological mission financed by the Ministry of Education. In 1892, he visited Syria accompanied by the journalist Charles Lallemand who became Gervais-Courtellemont's father-in-law in 1893. By this time he had a laboratory of photogravure in Alger (Gervais-Courtellemont et Cie.). In

46 This is the reason for his double family name. For more biographical information, see Guy Courtellemont, Le pionnier photographe de Mahomet (Nimes: Lacour, 1994); Béatrice De Paste, and Emmanuelle Devos, Les couleurs du voyage: L'œuvre photographique de Jules Gervais-Courtellemont (Paris: Paris musées/Phileas Fogg, 2002).

47 In 1925, Courtellemont described the scene in this way: "Nous sommes en 1874. Dans la vaste plaine de Relizane, qu' encerclent des montagnes déboisées et arides, une ferme blanche au toit rouge s' est édifiée. Un colon est venu pour tenter fortune. Ce n' est point une ambition démesurée qui l'a conduit là, mais bien plutôt le désir de se rendre utile. Il sait que, si la France veut s'implanter définitivement sur la terre africaine, il faut tout d' abord la peupler de colons français. Il vient de prendre sa retraite d'officier supérieur, il est marié, beau-père de deux garçons. La tourmente de 1870 a englouti la petite fortune de la famille. Il ne lui reste que 70.0oo francs liquides. Mais on lui a dit que cette somme était largement suffisante pour entreprendre la culture de la Ramie et du Ricin dans la plaine de Mina. Il n' en a pas demandé davantage pour se mettre à l' œuvre." De Paste and Devos, Les couleurs du voyage, 122. 
1890-1893, he became the editor of the illustrated review L'Algérie Artistique et Pittoresque. In this period, before his Hajj trip, Gervais-Courtellemont made contact with such intellectuals as Pierre Loti, Jules Lemaitre, Guy de Maupassant, Victor and Paul Margueritte, and Leon Gautier. ${ }^{48}$ All of them shared a common passion for Islam and were friends of Jules Cambon as well. GervaisCourtellemont himself was also close to Cambon because one of his wife's brothers was the chief of the governor's political cabinet.

Gervais-Courtellemont's pilgrimage to Mecca was made possible due to his relationship with Djabila Hadj Akli, an Algerian merchant, who regularly travelled to the Hijāz for trade. Gervais-Courtellemont met Hadj Akli in 189o, when the latter was arrested after he had violated the ban on travelling to Mecca. Hadj Akli was released after Gervais-Courtellemont's interference and mediation with French officials. ${ }^{49}$ As a result, Hadj Akli and Gervais-Courtellemont became very close friends. At the same time, Gervais-Courtellemont started to play a role in influencing Cambon's policy towards Islam in Algeria. In 1893, Hadj Akli managed to get a fatwā issued from Mecca in which the legitimacy of the infidels ruling over Muslims was questioned (see the French translation of the fatwa in the appendix). ${ }^{50}$

The following year, Hadj Akli accompanied Gervais-Courtellemont to the Holy City of Mecca. This Hajj trip had religious, cultural, and diplomatic objectives. Gervais-Courtellemont had certainly a sincere passion for Islam, and he embarked on the Hajj as part of his conversion. At the same time, he was also moved by his career as a traveller and photographer. ${ }^{51}$ To be one of the few Europeans who had visited the Holy City of Islam in the nineteenth-century was also certainly a great stimulus for him. Moreover, Gervais-Courtellemont was aware of the political dimension of his trip by trying to give it an official character. Although he did not succeed in obtaining an official mission from the Ministry of Education after the interference of the Foreign Ministry, he received a secret

48 See Courtellemont, Le pionnier photographe.

49 See Jules Gervais-Courtellemont, Mon voyage à la Mecque (Paris: Hachette, 1896).

5o The text of this fatwa a, provided with a French translation, is available in ANOM, F.80.1747.

$5^{1}$ Before embarking on his trip from Marseille, Gervais-Courtellemont came in contact with the editor of Imprimeries Réunies in Paris who offered to publish his Hajj travelogue if he brought back some snapshots from Mecca. In a letter to her brother Paul Lallemand, Hélène Courtellemont writes about her husband's pilgrimage: "ce voyage qu' il va faire sera long, 4 ou 5 mois, et très périlleux. Si Courtellemont s' en tire bien, il s' installera à Paris à la fin d'octobre avec un bon traité qu' il vient de conclure avec les Imprimeries Réunies, d' ici là il fermera sa maison d'Alger et n' entreprendra aucun travail." Hélène Courtellemont to Paul Lallemand, 26 avril 1894, quoted in De Paste and Devos, Les couleurs du voyage, 18. 
informal non-financed political mission from Governor Cambon. Among his tasks during the mission were the verification of the authenticity of the fatwa which Hadj Akli had brought back from Mecca, an evaluation of the French political and economic influence in the Hijāz, and the establishment of contacts with some political leaders in Arabia, possibly including the Sharif of Mecca. Thus Gervais-Courtellemont travelled to Arabia not only as a pilgrim and traveller-photographer, but as an informal French diplomat as well.

\section{Hajj Voyage and Report}

Gervais-Courtellemont arrived in Arabia in the autumn of 1894, some months after the regular period of the annual Hajj season. Together with his guide, they arrived in Jeddah on September 25. After a short religious training, they left for Mecca on October 6, where they were received by the Maghrebi muțawwif Abderraman Bou Chenak. Gervais-Courtellemont was immediately brought to the Great Mosque in order to achieve the first tawäf and to accomplish the rite of 'Umra (minor pilgrimage). Then he performed the Sac (shuttling between the two hills of al-Ṣafā wa al-Marwā), drank from the Well of Zamzam and had his hair cut. As it was Friday, he had the opportunity to listen to the sermon in the afternoon in the Great Mosque. In enthusiastic terms, GervaisCourtellemont described his fulfilment of these rituals as the most important mystical experience of his life.

Gervais-Courtellemont stayed for three days in Mecca where he was hosted by the Maghrebi mutawwif. Accompanied by a Moroccan resident in Mecca under the name Abd-el-Wahad, Gervais-Courtellemont toured around the mountains outside Mecca, such as Minā, walked in the local market, took some photographs from the mountain Abū-Qubays, and met with some Meccan inhabitants. In addition, he had some religious conversations with muftī Scheik Habbeud, who issued the fatwa a regarding French legitimacy in Algeria that was brought by Hadj Akli. Scheik Habbeud affirmed the authenticity of his document handed by Hadj Akli and signed another document attesting the conformity of Gervais-Courtellemont's conversion to Islam..$^{52}$ Gervais-Courtellemont did not succeed in meeting the Sharif of Mecca who was on holiday in the city of Țầif, but met with one of his emissaries, Hadj Ahmed. On his return trip, 
Gervais-Courtellemont met the son of the Sharif in Suez who promised to persuade his father to get in contact with Cambon.

Upon his return to France in November 1894, Gervais-Courtellemont submitted a twenty-two page report to the governor in which he made a description of his trip as well as his views of the economic, political, and sanitary aspects of the Hajj. Gervais-Courtellemont gave a detailed analysis of the sanitary situation of the site of Minā, where the ritual of sacrifice takes place during the Hajj, partly in order to remove the negative image of this place in European debates on the Hajj. ${ }^{33}$ In his opinion, the most significant problem was the negative image of France existing in the Muslim world. In order to improve this image, he suggested that the government had to repatriate poor Maghrebi pilgrims who were stranded in Jeddah under terrible conditions. ${ }^{54}$ Moreover, pro-French propaganda booklets should be published in Arabic to be circulated in Mecca:

Les Arabes et les Musulmans indiens de la Mecque et de Djeddah sont très avides de lecture. (...) Leurs lectures favorites sont des livres de rêves (explication et signification des songes), les livres de magie, quelques romans de chevalerie et aussi des livres d'histoire sainte, ancienne et contemporaine. À signaler des livres imprimés en Syrie par des chrétiens, livres d' histoire sainte que, dans leur naïveté, ils ne tiennent même pas en suspicion malgré la vignette et le monogramme de Jésus imprimés en tête

Three copies of this report are available in ANOM, 1H30 ("Voyage à la Mecque effectué par M.M. Gervais Courtellemont \& Hadj Akli: juillet-octobre 1894").

"Voyage à la Mecque," ANOM, 1H30, 17-18: "On critique beaucoup le consulat français de Djeddah. On lui reproche, entre autres griefs, d' abandonner les Maugrebins indigents (...) Or quelques Algériens et Tunisiens et beaucoup de Marocains et Tripolitains indigents, absolument dénoués de ressources arrivent à se faufiler, au départ, parmi les pèlerins. Ils subsistent comme ils peuvent pendant la durée du pèlerinage, mais, les cérémonies religieuses terminées et tout le monde parti de Djeddah, ils errent, lamentables par les rues et les places, mourant de faim, excitant la compassion de leur coreligionnaires par leur extrême dénuement, leur misère, et leur abandon qui persiste, alors que Turcs et Égyptiens sont depuis longtemps rapatriés par le soins de leurs gouvernements respectifs qui consacrent chaque année de grandes sommes à cette œuvre de charité. Il faudrait je crois faire appel à la charité musulmane en Algérie et en Tunisie pour recueillir des offrandes qui seraient centralisées et remises à un personnage influent du pèlerinage, chaque année, par le consulat de Djeddah qui veillerait en même temps à la répartition judicieuse de ces fonds. On rapatrierait au besoin les Marocains quitte à mettre à profit, très ostensiblement auprès de Sa Majesté Chérifienne pour lui prouver nos bons sentiments à l' égard de ses nationaux, l' exercice de cet acte d'humanité." 
du livre et l' absence du 'Bismilla' à la première page. Étant donné un tel état d' esprit, je crois qu' il serait très important pour le développement de l'influence française, de faire imprimer un livre de l'histoire de l' Algérie et de la Tunisie que l'on s' efforcerait de répandre à profusion. Ce livre, commencé par le récit politique des grands combats de la conquête en ne négligeant pas de citer les exploits fameux des héros arabes de l'époque, se terminerait par une description de l'état prospère actuel de ces pays protégés par la France. On y représenterait l'action de la France, non oppressive, comme ils se plaisent à la dire, mais bien faisant, tutélaire et pleine d'égards pour la foi musulmane..$^{55}$

Finally a mosque should be built in Paris as the British had already done in London: "Tout cela part d'un point reconnu exact. Il existe en effet à Londres une petite mosquée et c'est à la vérité la seule qui existe en Europe ou tout au moins dans l'extrême occident. (M. le prince d'Arenberg m'a dit qu'il s' occupait en ce moment de faire aboutir l' idée d' en construire une à Paris)." ${ }^{n 6}$

In that report, Gervais-Courtellemont underlined the active political role played by the British Consulate in Jeddah and the British strategy of gaining popularity among Muslims:

À signaler aussi au point de vue des efforts faits par les Anglais pour développer leur influence en Arabie: 1) L' organisation de leur Consulat. Leur consul est secondé par un chancelier très remarquable, docteur indien il habite depuis 12 ans Djeddah et exerce gratuitement la médecine auprès des indigents de ses nationaux. Il a à sa disposition toute une pharmacie installée au Consulat. Le $1^{\mathrm{er}}$ drogman est enfant de Djeddah et connaît tous les habitants de Djeddah et de la Mecque. 2) Le consulat Anglais ne cesse d'obséder les autorités turques des revendications de ses nationaux. Les autorités turques s' en sont même plaint à Constantinople, on le sait à Djeddah et cela fait très bon effet les Turcs étant méprisés et détestés. 3) Ils entretiennent des relations politiques suivies avec le Soudan et l'Afrique par Souakim; ils ont dans ce but un agent secret, Smain Nebelaoui. ${ }^{57}$

\footnotetext{
55 "Voyage à la Mecque," ANOM, 1H30, 18-19.

56 "Voyage à la Mecque," ANOM, $1 \mathrm{H}_{30}, 20$.

57 "Voyage à la Mecque," ANOM, 1H30, 20-21.
} 


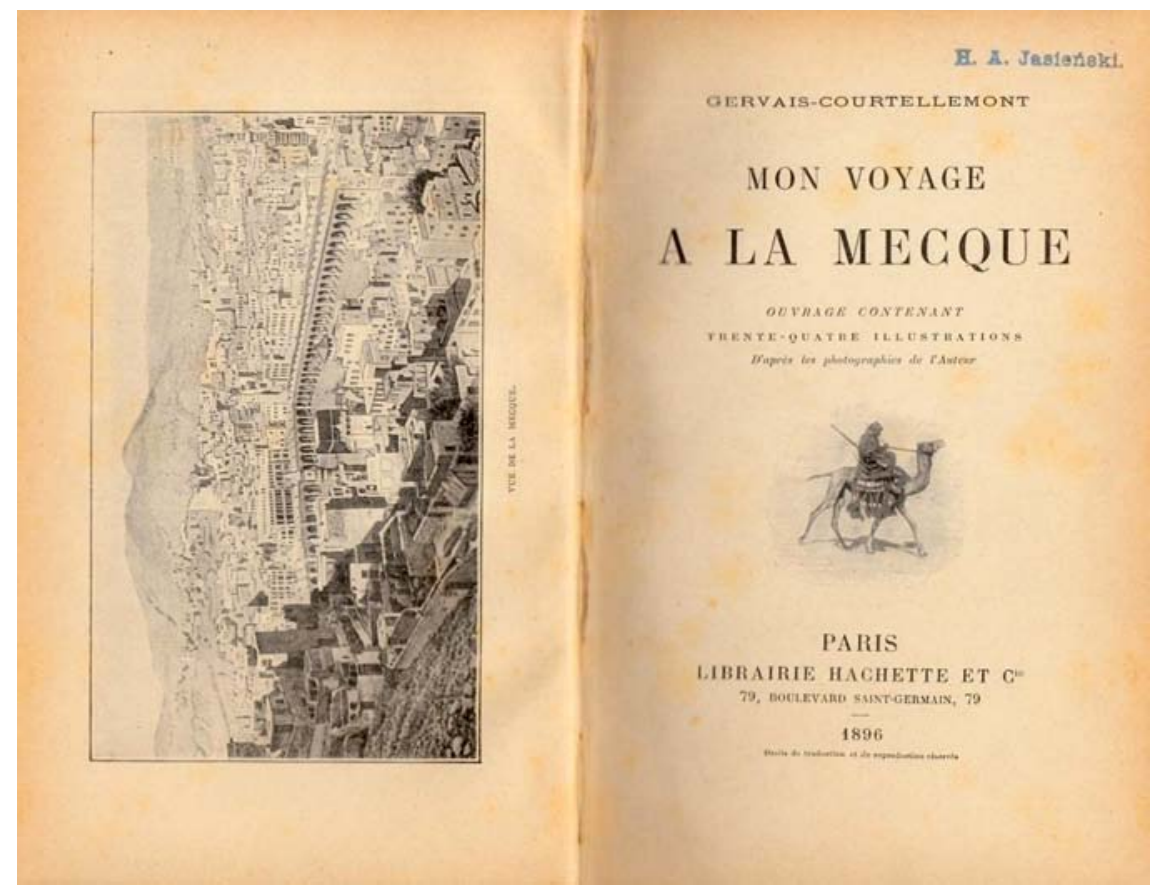

FIGURE 4.1 Front page of Gervais-Courtellemont's travelogue

In December 1894, Gervais-Courtellemont gave two public lectures in Paris, at the Société de Géographie Commerciale and at the Société de Géographie, in which he explained his Arabian experience. Moreover, the illustrated review Le Monde Illustré had published an article on his trip. After his return to Algiers in January 1895, he was awarded a decoration of Légion d'honneur with the signature of Jules Cambon and held another lecture at the École des beaux arts d'Alger. Back in France he gave other public lectures in Lyon and Bordeaux about the religious and political situation in the Hijāz in order to publicise for Jules Cambon's above-mentioned Islam and Hajj policy.

\section{Controversy over Courtellemont's “Minor” Pilgrimage}

Gervais-Courtellemont's observance of the 'Umra ritual should be seen neither as an intelligence operation by a secret agent nor as a scientific inquiry by an ethnographer. ${ }^{58}$ As a Muslim convert, his entrance to Mecca cannot be catego-

$5^{8}$ See Christiaan Snouck Hurgronje, "Les confréries religieuses, La Mecque et le panislamisme," Revue de l'histoire des religions 44/2 (1901), 262-281. 
rized as a clandestine European adventure. His Mecca journey provoked hotlydebated discussions in the French colonial administration and public opinion.

Albert Édouard Bobot-Descoutures, the French Consul in Jeddah in 1895, saw Gervais-Courtellemont's visit to Arabia in a negative light by labelling it as a mission of an "improvident amateur" that had damaging effects on French influence and interests in Arabia. Bobot-Descoutures cast doubts on the sincerity of Courtellemont's conversion to Islam, describing it as a "stratagem to satisfy his profane curiosity."59 We should not forget that such accusations were also part of the divergent views between the French Consulate to Jeddah and the Algerian colonial office regarding the Hajj. The consul certainly did not appreciate Jules Cambon's pressure on the French policy in the Hijāz. ${ }^{60}$ Due to his informal diplomacy, Gervais-Courtellemont was also probably a controversial figure in French diplomatic circles. In 1901-1903, he undertook a mission to the Chinese region of the Yunnan, which the French consul to the region Auguste François (1857-1935) heavily criticized. ${ }^{61}$

In 1895, a slander campaign in the Daily Telegraph arose, which was probably initiated by some Egyptians and Ottomans in Arabia in order to discredit Gervais-Courtellemont's sincerity. As these accusations soon reached Algeria, some newspapers, such as La Revue Algérienne, Le Tell, L'Étoile Africaine, and La Vigie Algérienne, immediately started to orchestrate a strong campaign against Gervais-Courtellemont as well. In this he was accused as an "impostor" whose mission to Arabia was nothing but a farce and his conversion was a way of deception. In a sarcastic manner, such press articles belittled GervaisCourtellemont's decoration as well as Cambon's promotion of his "ridiculous" and "improvident" Hajj proposal. ${ }^{62}$

In order to refute this slander campaign, Gervais-Courtellemont responded in the newspaper Le Petit Colon Algérien (March 20, 1895) by stating:

Mais peu importe d' ailleurs, je fournirais mon œuvre. Je décrirai fidèlement et sincèrement ces pays et ces populations d'Islam si méconnues; j' appliquerais toutes mes facultés à redresser les erreurs involontaires ou volontaires qui ont généralement couru. Je prouverai que 250 millions de

59 Courtellemont, Le pionnier photographe, 80-81: "une supercherie uniquement destinée à lui permettre de satisfaire sa curiosité profane."

6o Courtellemont, Le pionnier, 81 .

61 Courtellemont, Le pionnier, 117. See Jules Gervais-Courtellemont, "La France en Asie: du fleuve rouge au fleuve bleu par le Yunnan," Bulletin de la société de géographie de Toulouse 1 (1904): 14-24.

62 See, La Vigie Algérienne, January 27, May 1 and 7, 1895. 
créatures humaines obéissant la même foi ne méritent pas l'oubli ou le mépris auxquels on les condamne et dans l' avenir plus encore que dans le présent, mes amis de la Mecque et du monde Musulman ne regretteront pas d'avoir placé en moi leur estime, leur confiance et leur sympathie. Leur civilisation n' est pas d'accord avec celle des pays européens mais elle n' en est pas moins une des plus grandes manifestations morales de l'Humanité. Comme vous l' avez si justement dit dans vos précédentes articles sur mon voyage je suis une preuve vivante de l' apaisement moral qui se fait aujourd'hui sur ces questions. Au retour des pèlerins de la Mecque, dans quelques semaines, l' opinion des honnêtes gens sera plus que jamais édifiée sur ma sincérité, mais en attendant je n'ai pu résister au besoin de protester contre les vils agissements d'imposteurs plus ou moins intéressés. ${ }^{63}$

He also did an interview with the director of Le Matin in which he strongly attempted to prove the authenticity of his undertaking and the sincerity of his conversion to Islam by denouncing the inaccuracies brought forward by journalists against him.

In the public debate about Jules Cambon's Islam policy, Gervais-Courtellemont brought fresh observations about the sanitary and political situation of the Hijāz, which contrasted with common views on this Muslim ritual. His reflections on the Hajj and Arabia were published in the French press as the expertise of un français-musulmanisé. His views as a French Muslim citizen, belonging to a middle-class family, represented a problem for Cambon's rivals in the diplomatic office and had an impact on the terms of the debate on the Hajj. To question his sincerity to Islam as a French Muslim convert was a way of discrediting his Hajj proposals that were in harmony with Cambon's ambitions.

In 1896 , the well-known publishing house Hachette was keen on publishing Gervais-Courtellemont's travelogue under the title, Mon voyage à la Mecque. ${ }^{64}$ The author tried to debunk the French "prejudices" against the Hajj and affirmed the need for a more tolerant Islam policy, as Jules Cambon in Algeria had earlier proposed. Taking Hadj Akli's arrest and ban of travel to Mecca, for example, he attempted to demonstrate the absurdity of any plans proposing the prohibition of the Hajj. For him, the "inhumane" conditions of the Maghrebi pilgrims stranded in Jeddah were indication of the absence of a clear French

63 "El-Hadj Courtellemont: Réponse d'un calomnié," Le Petit Colon, March 20, 1895.

64 Jules Gervais-Courtellemont, Mon voyage à la Mecque (Paris: Hachette, 1896). 
policy for the protection of pilgrims that would safeguard France's honour. The fact that the Consulate was not aware of his trip to Arabia showed the "inefficiency" of their diplomatic work in the Hijāz. By describing his religious spiritual experience in Mecca, Gervais-Courtellemont tried to introduce a different approach to the Hajj and to the Muslim world from a more positive angle. In his life Gervais-Courtellemont never abandoned Islam and continued his profession as a photographer. In 1931, he died and was buried nearby Paris dressed in his Ihräm clothing and with a copy of his conversion certificate in his hand. ${ }^{65}$

\section{Conclusion}

Our previous inquiry about French colonial policy regarding the Hajj in Algeria the late nineteenth century affirms Triaud's remarks that "there is an antiIslamic dimension inherent and recurrent in French political and administrative thought that merits study and inquiry. Although there have been authors, and periods, manifesting interest and sympathy for Muslim world, French culture has maintained strong continuity in its negative view and fear of Islam." 66

Despite their different political and social backgrounds, Cambon and Courtellemont were convinced of the need for a radical change in the French Hajj policy. In his colonial office Cambon was able to demonstrate the political and economic advantages of the French rule of the Hajj. However, his policy was heavily obstructed by others administrators and public opinion. As a French native and convert to Islam, Gervais-Courtellemont, on the other hand, influenced the debate on the Hajj in France. His views triggered strong reactions in diplomatic circles and in public opinion, which were combined by inaccurate images and prejudice against Islam in the colonial context.

The slander campaign against him was mostly mirrored in a rejection of the authenticity of his conversion to Islam and religious practices in Mecca. Labelling him an "impostor," "swindler," and "naïve" was intended as underlying dismissal of an emerging French-Muslim identity in the colonial era. As a matter of fact, in that period positive and sympathetic attitudes towards Islam emerged in France, such as the promotion of a mosque building in Paris, the

65 Myriam Harry, “Gervais-Courtellemont," Le Temps, November 8, 1931.

66 Jean-Louis Triaud, "Islam in Africa under French Colonial Rule," The History of Islam in Africa, ed. N. Levtzion, and R.L. Pouwels (Athens-Oxford-Cape Town, Ohio University Press-James Currey-David Philip, 2000), 169-170. 
establishment of a pro-Islam journal, La Revue de l'Islam, and the emergence of such intellectual movements as islamologie positive. ${ }^{67}$

From ANOM, GGA: F.80.1747

Le Gouverneur général de l' Algérie, Jules Cambon, au président du Conseil et ministre de l'Intérieur, Charles Dupuy

Alger 2 novembre 1893

Monsieur le Président,

Le Maréchal Bugeaud avait jadis envoyé son savant interprète, M. Léon Roche, à la Mecque, afin d'obtenir une consultation des Chorfa de la Ville Sainte, établissant que les Musulmans pouvaient obéir aux chrétiens lorsque ceux-ci respectaient leur religion. Léon Roche réussit dans sa mission et cette consultation ou Fetouah nous rendit les plus grands services lors de l'établissement de notre domination.

Préoccupé d' aider notre action dans les oasis de l'Extrême Sud de tous les moyens d' action qui la feront plus aisément accepter, j' ai toujours cherché à mettre de notre côté les influences religieuses qui dominent au Touat et au Gourara, celles des Taybia et celles des Oulad Sidi Cheikh, et j' avais fait venir à Alger un jeune neveu du chérif d'Ouazzan afin de lui faire suivre notre colonne. Ce jeune homme est actuellement à Tlemcen, où il attend mes instructions soit pour retourner au Maroc, soit pour descendre vers les oasis de l' Extrême Sud.

Il m'avait paru également nécessaire de reprendre ce qu'avait si heureusement tenté le maréchal Bugeaud, et, l' année dernière, je demandai à M. Ribot l' autorisation d' envoyer quelques cadeaux aux Chorfa de la Mecque à l' occasion du pèlerinage. Cette année, à la suite du pèlerinage, j' ai reçu une Fetouah dans laquelle les Chorfa des trois ordres religieux établis dans le nord de l'Afrique, les Hanéfites, les Malékites et les Chafaites, répondent à la question posée de savoir si les musulmans peuvent obéir aux infidèles. Cette Fetouah, que l'on pourrait comparer à certains mandements, est un santon de citations sacrées et écrite dans le style plein de détours des documents de cette nature. Elle n'en est pas moins très intéressante et précieuse et les Musulmans, qui ont des façons de parler enveloppées et discrètes, en comprendront la portée. Je l'ai reproduite exactement à l' Imprimerie nationale, mon dessin étant de la faire répandre au Touat lorsque nos troupes y arriveront et ce n' est pas sans regret que je vois aujourd' hui toutes les mesures que j' avais prises pour faire accepter notre autorité

67 See, for example, Sadek Sellam, La France et ses musulmans: Un siècle de politique musulmane (1895-2005) (Paris: Fayard, 2006). 
sans trop d'opposition et dont l'ensemble concourait au même but devenues aussi inutiles. L'occasion est fugace et ne se retrouve pas.

Quoi qui il en soit, j' ai l' honneur de vous adresser avec la traduction la reproduction de cette Fetouah comme un document qui pourra nous intéresser.

Veuillez agréer, Monsieur le Président, l'assurance de mon respectueux dévouement

Le Gouverneur Général Jules Cambon.

\section{FATWA}

Gouverneur Général de l'Algérie.

Traduction de la Fetoua envoyée de la Mecque au

Gouverneur Général de l' Algérie.-Pèlerinage de 1894

\section{Question.}

Des musulmans sont établis dans une localité dont les infidèles ont fait la conquête. Ceux-ci les administrent sans faire le moindre obstacle à l' exercice de la religion musulmane; ils vont même jusqu' à encourager les musulmans à pratiquer leurs devoirs religieux. Ils leur donnent pour exercer les fonctions de cadi un de leurs coreligionnaires musulmans chargés de faire exécuter les prescriptions de la loi musulmane et assurant à ce fonctionnaire des émoluments convenables qu'il perçoit régulièrement au commencement de chaque mois. Dans ces conditions, les musulmans doivent-ils: $1^{\circ}$ émigrer ou non $? 2^{\circ}$ entrer en lutte avec les infidèles et chercher à leur enlever l' autorité, même s'ils ne sont point assurés d'avoir le pouvoir nécessaire pour le faire? La localité dont les infidèles ont fait la conquête doit elle être considérée comme terre d'islam ou comme territoire en état de guerre? Donnez-nous sur ces trois points des renseignements complets et des arguments décisifs qui coupent court à toute discussion antérieure. Que Dieu par vos soins fortifie sa religion!

\section{Réponse.}

Notre savant maître (Dieu lui fasse miséricorde!) nous a déjà fait connaître son opinion en répondant à la question suivante qui lui avait été posée: «Un musulman est-il tenu d'émigrer d' une localité dans laquelle, pur un motif quelconque, il ne peut accomplir tous les devoirs que sa religion lui impose?»

Sa réponse était conçue en ces termes: «Celui qui ne peut s' acquitter des prescriptions dont la religion lui fait un devoir, doit émigrer de la localité dans laquelle il se trouve s' il est en état de le faire, c' est-à-dire s' il a une fortune suffisante lui permettant de changer de résidence. En parlant des gens qui avaient embrassé l' islamisme et qui 
n' avaient point émigré alors qu' ils en avaient les moyens, Dieu a dit: «Les Anges, en ôtant la vie à ceux qui avaient agi uniquement envers eux-mêmes, leur demandèrent: Qu'avez-vous fait? Ils répondirent: «Nous étions les faibles de la terre». Les Anges leur dirent: «La terre de Dieu n' est elle pas assez vaste? Ne pouviez vous pas, en abandonnant votre pays, chercher un asile quelques part?» (Coran chap. IV, verset 99). Ainsi Dieu n'a pas excusé ces gens-là et cependant ils étaient faibles et incapables d'émigrer vers une autre localité. Toutefois il a fait ensuite une exception dans le verset suivant en disant: «Sauf les faibles parmi les hommes, les femmes et les enfants.»

«Ce qui revient à dire que l'enfer sera la demeure de tous ceux qui ont refusé d'émigrer, à moins qu'ils ne soient au nombre des faibles parmi les hommes, les femmes et les enfants, car alors ils sont incapables de trouver une combinaison qui leur permette de fuir, c'est-à-dire que, par suite de leur faiblesse physique ou de leur extrême misère, ils ne sont point en état de se diriger dans leur route ou, en d' autres termes, de reconnaître la voie qu' ils devraient suivre. C' est à ceux-là que Dieu pardonnera s' ils n' émigrent pas ». Ici se termine la réponse de notre savant maître.

Les plus éminents exégètes du Coran ont exprimé la même opinion et le Prophète (que Dieu répande sur lui ses bénédictions et lui accorde le salut!) a dit: «Celui qui, à cause de sa religion, quitte un pays pour se rendre dans un autre, même s' il n' avait à parcourir pour cela que la distance d'un empan, aura mérité le Paradis et il sera le compagnon de son ancêtre Abraham et des descendants de celui-ci parmi lesquels figure Mahomet (que Dieu répande sur eux toutes ses bénédictions!)».

Dans le Miràdj ed-dirâqa d' après le Mebrout, on trouve ce qui suit: «Les pays entre les mains des infidèles restent terre d'islam et ne deviennent pas territoires en état de guerre, quand ceux-ci n'y font point régner leurs lois et qu' au contraire ils y ont institué des cadis et des fonctionnaires musulmans qui leur sont soumis volontairement on non. En effet dans toute ville où il y a un chef musulman il lui est permis de faire l'office du Vendredi, de célébrer les fêtes religieuses et d'appliquer les pénalités de la loi musulmane. Si les fonctionnaires sont des infidèles, les musulmans pourraient encore avoir liberté de célébrer l'office du Vendredi et de choisir parmi eux un cadi agréé par tous les fidèles, mais ils devront alors demander qu'on leur donne un chef musulman».

Dans le Tenouïr-el-Abçâr et dans son commentaire intitulé: Ed-dorr-el-Mokhtâr, il est dit: «Une des trois conditions suivantes est nécessaire pour qu' une terre d'islam devienne un territoire en état de guerre; ainsi il faut: $1^{\circ}$ ou que la loi des infidèles y soit appliquée; $2^{\circ}$ ou que le pays soit annexé à un territoire en état de guerre; $3^{\circ}$ ou qu'il n'y reste plus un seul musulman ou un seul tributaire qui jouisse de la première des sécurités, celle qui lui garantit son existence».

Le célèbre Eth-Thahthaouï a donné une glose de ce passage et il semble en résulter que toutes les fois que les lois musulmans sont appliquées en même temps que les lois des infidèles, le pays n' est pas dit territoire en état de guerre. 
Par tout ce que nous venons de raconter, on voit que, du moment qu' il y a un cadi, fût-il nommé par les infidèles, et que les lois musulmanes sont appliquées comme il a été dit ci-dessous, un pays ne cesse pas d'être terre d'islam. Dieu sait mieux que personne ce qui il en est de tout cela.

Les présentes lignes ont été tracées par ordre du serviteur de la loi musulmane, mufti de la glorieuse ville de la Mecque.

Louange au Dieu unique. Que Dieu répande ses bénédictions sur Notre Seigneur Muhammad, sur sa famille, sur ses Compagnons et sur tous ceux qui après lui marchent dans le bon chemin. O mon Dieu, sois notre guide dans la recherche de la vérité! Dans les Fetouas du savant des savants cheikh, Mohammed ben Seliman El Kurdi, l' auteur d'une glose marginale sur le Commentaire d'Ibn Hadjar, on trouve ceci: «Le séjour des musulmans sur un territoire appartenant aux infidèles peut être rangé dans un des quatre catégories suivantes: $1^{\circ}$ où il est obligatoire, $c^{\prime}$ est-à-dire que les musulmans peuvent bien se soustraire à l' adoption de la religion des infidèles et vivre à l' écart, mais qu'ils n'ont plus à espérer aucun secours des musulmans. Ce pays reste terre d'islam tant que les musulmans n' en ont point émigré; dans ce cas seulement il deviendrait un territoire en état de guerre; $2^{\circ}$ où il est toléré, par exemple quand les musulmans peuvent professer ouvertement leur religion et qu' ils ont l' espoir de voir ce pays revenir un jour à leurs coreligionnaires; $3^{\circ}$ où il est répréhensible, c' est dans le cas où pouvant exercer leur culte ils n' ont plus aucun espoir de voir le pays revenir aux mains des musulmans; $4^{\circ}$ où enfin il est absolument interdit, c' est quand les musulmans ne peuvent plus y professer ouvertement leur religion ». En conséquence, si l' exercice de la religion musulmane et l' application de la loi islamique dans toutes ses parties doivent être une cause de ruine ou de mort pour les musulmans parce que les fonctionnaires choisis parmi les infidèles exercent seuls l'autorité sans tenir compte des injonctions de la loi musulmane, il est interdit au musulman de demeurer dans un tel pays et tous devront le quitter sauf ceux qui seront dans l'impossibilité matérielle de le faire et ces derniers seuls seront excusables.

Dans le commentaire de Eldjémâl El-remli sur le Minhadj el-Aoudjah, il est dit: «sera terre d'islam tout pays dont les infidèles auront fait ainsi la conquête, c' est-à-dire qu'il y aura lieu de distinguer les catégories énumérés ci-dessus». Ceci répond donc à la première partie de la question qui a été posée. Pour la deuxième partie, on doit répondre qu' il n' est pas obligatoire d' entrer en lutte avec les infidèles puisqu' on n' est pas capable de le faire avec succès. Enfin, pour la troisième partie, la réponse à faire st que la terre d'islam ne devient pas territoire en état de guerre par le seul fait de la conquête des infidèles. Dieu sait mieux que personne si ceci est exact. Ecrit par celui qui espère tout du seigneur. Mohammed Saïd ben Mohammed, mufti des chaféites à La Mecque (que Dieu le protège!). Dieu lui pardonne ainsi qu'à ses parents, à ses maîtres et à tous les musulmans. 
Louange au Dieu unique. O mon Dieu, sois notre guide dans la recherche de la vérité! Arès avoir épuisé les résultats des recherches faites ci-dessus par mes savants confrères, j' ai reconnu qu' ils étaient conformes à la vérité et qu' ils devaient fournir la seule base solide des réponses demandées. Dieu accorde la meilleure des récompenses à ces maîtres et maintienne par eux les pratiques de la religion! C'est lui qui est le vrai soutien.

Écrit par ordre du Mufti malékite à la Mecque (que Dieu le protége!), Mohammed 'Abed, fils du défunt Cheick Hoseïn.

\section{Bibliography}

Ageron, Charles-Robert. Les Algériens musulmans et la France (1871-1919). Paris: Presse Universitaire de France, 1968.

Boyer, Philippe. "L'administration française et la réglementation du pèlerinage à la Mecque (1830-1894)." Revue d'Histoire Maghrébine 9 (1977): 275-293.

Cambon, Jules. Le Gouverneur Général de l'Algérie (1891-1897). Paris: Champion, 1918.

Chantre, Luc. "Se rendre à La Mecque sous la Troisième République: Contrôle et organisation des déplacements des pèlerins du Maghreb et du Levant entre 1880 et 1939." Cahiers de la Méditerranée 78 (2009): 202-227. Accessed March 31, 2014. url: https://cdlm.revues.org/4691.

Charle, Christophe. Les Élites de la République 1880-19oo. Paris: Fayard, 1987.

Charmes, Gabriel. La Tunisie et la Tripolitaine. Paris: Calmann Lévy, 1883.

Charmes, Gabriel. Politique extérieure et coloniale. Paris: Calmann Lévy, 1885.

Courtellemont, Guy. Le pionnier photographe de Mahomet. Nîmes: Lacour, 1994.

D’Agostini, Aldo. “De l' usage diplomatique du discours sur le panislamisme: La correspondance de l' ambassadeur français à Istanbul Charles-Joseph Tissot, lors de la crise tunisienne de 1881." Archiv Orientální / Oriental Archive:Journal of African and Asian Studies 81/2 (2013): 149-172.

Daniel, Norman. Islam, Europe and Empire. Edinburgh: Edinburgh University Press, 1966.

D'Avril, Adolphe. L'Arabie contemporaine avec la description du pèlerinage de la Mecque et une nouvelle carte géographique de Kiepert. Paris: Maillet-Challamel Ainé, 1868.

Delarue, L. Rapport médical de M. Delarue commissionné par M. le Gouverneur général de l'Algérie à bord du Pictavia pour le pèlerinage de la Mecque en 1891. Alger: Giralt, 1892.

De Paste, Béatrice, and Emmanuelle Devos. Les couleurs du voyage: L'œuvre photographique de Jules Gervais-Courtellemont. Paris: Paris musées/Phileas Fogg, 2002. 
Depont, Octave, and Xavier Coppolani. Les confréries religieuses musulmanes. Alger: Jourdan, 1897.

Escande, Laurent. "Le pèlerinage à la Mecque des Algériens pendant la domination française (1830-1962).” DEA diss., Université de Provence, 1992.

Gervais-Courtellemont, Jules. Mon voyage à la Mecque. Paris: Hachette, 1896.

Gervais-Courtellemont, Jules. "La France en Asie: du fleuve rouge au fleuve bleu par le Yunnan." Bulletin de la société de géographie de Toulouse 1 (1904):14-24.

Guignard, Didier. L'abus de pouvoir dans l'Algérie coloniale (1880-1914): Visibilité et singularité. Paris: Presses Universitaires de Paris Ouest, 2010.

Hajjar, Joseph. L'Europe et les destinées du Proche-Orient III: Bismarck et ses menées orientales 1871-1882. Damascus: Dar Tlass, 1990.

Harry, Myriam. "Gervais-Courtellemont." Le Temps, November 8, 1931.

Massaia, Guglielmo. Lettere e scritti minori. Roma: Istituto Storico dei Cappuccini, 1978. Proust, Adrien. La défense de l'Europe contre le Cholera. Paris: Masson, 1892.

Rodinson, Maxime. La fascination de l'islam: Les étapes du regard occidental sur le monde musulman: Les études arabes et islamiques en Europe. Paris: Maspero, 1980.

Roff, William. "Sanitation and Security: The Imperial Powers and the Nineteenth Century Hajj." In Arabian Studies VI, edited by R. Serjeant and R. Bidwell. London: Scorpion Communication-University of Cambridge, 1982. 143-160.

Sellam Sadek. La France et ses musulmans: Un siècle de politique musulmane (18952005). Paris: Fayard, 2006.

Snouck Hurgronje, Christiaan. "Les confréries religieuses, La Mecque et le panislamisme." Revue de l'histoire des religions 44/2 (1901): 262-281.

Suret, Édouard-Florent. Lettre sur le cholera du Hedjaz. Paris: Masson, 1883.

Tabouis, Geneviève. Jules Cambon par l'un des siens. Paris: Payot, 1938.

Triaud, Jean-Louis. La légende noire de la Sanûsiyya: Une confrérie musulmane saharienne sous le regard français (1840-1930). Paris: Éditions de la Maison des sciences de l'homme, 1995.

Triaud, Jean-Louis. “Islam in Africa under French Colonial Rule." In The History of Islam in Africa, edited by N. Levtzion and R.L. Pouwels. Athens-Oxford-Cape Town, Ohio University Press-James Currey-David Philip, 200o. 169-187.

Trumbull IV, George. An Empire of Facts: Colonial Power, Cultural Knowledge, and Islam in Algeria. Cambridge: Cambridge University Press, 2009.

Villate, Laurent. La République des diplomates: Paul et Jules Cambon 1843-1935. Paris: Science Infuse, 2002. 


\section{Archives}

AMAE (Archives du Ministère des Affaires Étrangères, Paris)

CP (Correspondance Politique)

- Turquie, vol. 434-436 (January-March 1880)

CC (Correspondance Consulaire)

- Tripoli de Barbarie, vol. 17, 18, 19 (1879-1881)

ANOM (Archives Nationales d'Outre-Mer, Aix-en-Provence) GGA (Gouverneur Général de l' Algérie)

- 1H H58: "Circulaires"

$-1 \mathrm{H} 31$ : "Mahdi et Turquie"

- 16H83/84: "Pèlerinages à la Mecque"

- F80.1747: "Pèlerinages à la Mecque"

- 1H30: "miscellaneous" 